\title{
Purple Urine Bag Syndrome; A Rare but Important Manifestation of an Important Disease
}

\section{Mor İdrar Torbası Sendromu; Önemli Bir Hastalığın Nadir Fakat Önemli Bir Belirtisi}

\author{
๑ Ümran Keskin, ๑ Polen Balin Kahraman, ๑ Pelin Özel, ๑ Kadir Kayataş \\ University of Health Sciences Turkey, Haydarpaşa Numune Training and Research Hospital, Clinic of Cardiology, İstanbul, Turkey
}

Purple Urine Bag syndrome (PUBS) is a rare and startling clinical situation commonly associated with urinary tract infection in patients with a urinary catheter. In previous reports, the underlying pathogens and mechanisms were found quite similar and there is not a report with a different further diagnosis in PUBS. In this report, we present a patient with PUBS for which the underlying pathogen and diagnosis is quite unique.

Keywords: Urine color, urinary tract infection, urothelial cancer, urinary catheter

Mor İdrar Torbası sendromu (PUBS) nadir ve çarpıcı bir klinik durum olup genellikle üriner kateter taşıyan hastalardaki idrar yolu enfeksiyonu ile ilişkilendirilmiştir. Geçmiş raporlarda altta yatan patojenler ve mekanizmalar oldukça benzer olarak bulunmuş olup PUBS'de farklı bir tanıya yönlendiren olgu rapor edilmemiştir. Bu yazıda altta yatan patojen ve tanısı oldukça benzersiz olan bir PUBS olgusu sunmaktayı.

Anahtar Kelimeler: İdrar rengi, idrar yolu enfeksiyonu, ürotelyal kanser, üriner kateter

\section{Introduction}

Urine color can be an important finding of various disorders and clinical situations. For example, white urine indicates lipiduria or chyluria, pink urine indicates glomerulonephritis, tea color urine indicates hemolysis or myoglobinuria, orange urine indicates rifampicin use, and blue-green urine indicates pseudomonas infection. Oxford urine table is dedicated to make a proper diagnosis in patients with abnormal urine colors (1). Purple Urine Bag syndrome (PUBS), which was first reported in 1978 , is another rare clinical situation that might point to urinary tract infection (UTI) (2). Additionally, purple urine can be seen in pediatric patients with Drummond syndrome (3). PUBS is usually seen in geriatric and immobilized patients with inserted Foley catheter, who is complicated with UTI (4). In this case report, we present a patient with bladder cancer, who was admitted to emergency department with PUBS.

\section{Case Report}

A 92-year-old male patient was admitted to our emergency department with the complaints of dysuria, hypotension, oliguria, and purple urination. The patient had a history of heart failure and chronic obstructive pulmonary disease and was hospitalized due to pneumonia in intensive care unit three weeks ago. He was followed-up with a urinary catheter in this period and discharged two days ago after the removal of the catheter. The patient did not have another systemic disorder. In physical examination, no abnormalities were found in flank region. The patient looked dehydrated and lethargic. The patient's bladder was palpable and suprapubic region was painful on palpation. Other systems' examination was normal. After the insertion of urinary catheter, we noticed that the urinary catheter bag and the urine within it had become a purple color (Figure 1). The urine test was positive nitrites, hemoglobin and 


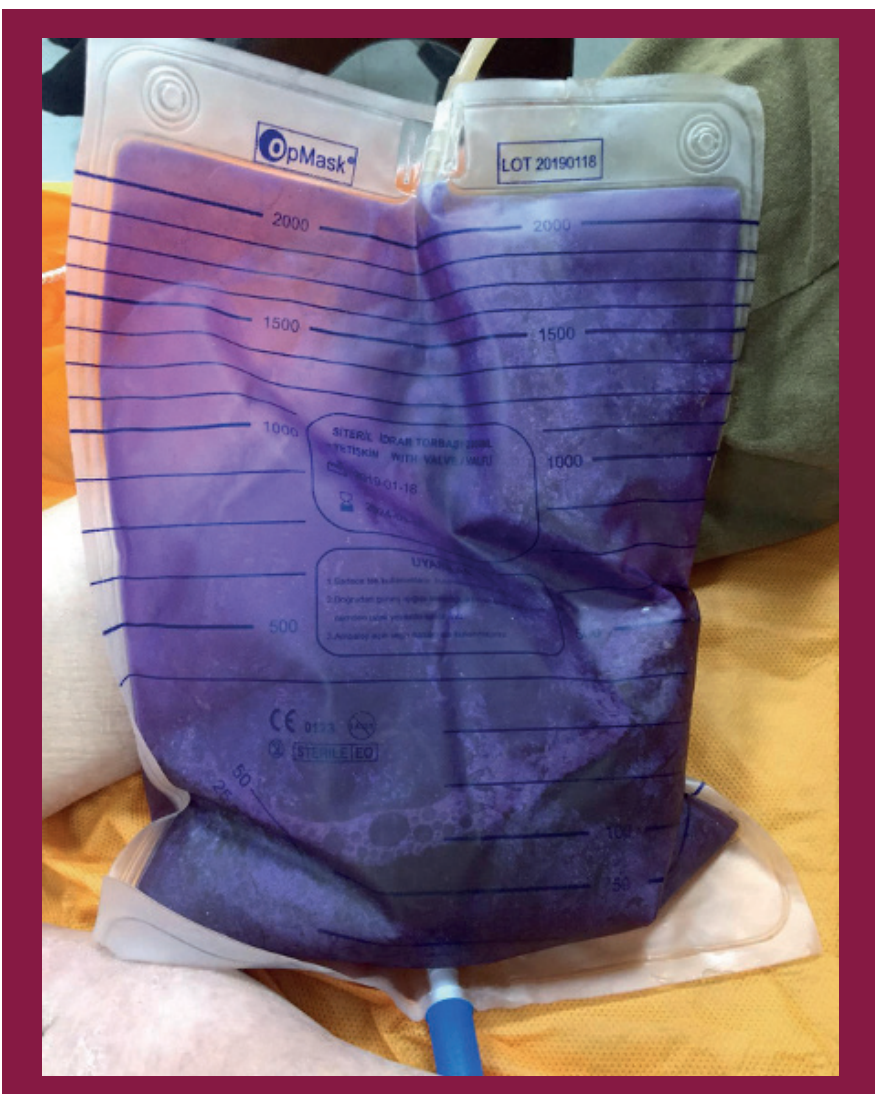

Figure 1 . The purple discoloration of urine which was observed after the insertion of urinary catheter

leucocytes and had a pH of 8.4. White blood cell count was 5.2 $10^{3 / \mu \mathrm{L}}$ and neutrophil count was $3.110^{3 / \mu \mathrm{L}}$. C-reactive protein was at $1.8 \mathrm{mg} / \mathrm{dL}$, and procalcitonin at $0.46 \mathrm{ng} / \mathrm{mL}$. Abdominal ultrasound demonstrated focal bladder wall thickening and contour irregularities. Post-void residual urine volume was 250 $\mathrm{mL}$. The patient was administered an empirical ciprofloxacin $500 \mathrm{mg}$, antibiotherapy twice a day after bacteriological sampling of urine. Urine culture for aerobic bacteria, anaerobic bacteria and yeast was carried out before the administration of antibiotics. Morganella morganii culture results showed significant growth after 24 hours, which was sensitive to ciprofloxacin. After the administration of ciprofloxacin therapy (400 mg q12h) for two days, the urine returned to a clear yellow color. After the completion of antibiotherapy, the patient underwent transurethral cystoscopy to take a biopsy from the bladder. Pathological examination of the sample revealed a low grade papillary urothelial carcinoma. The patient underwent transurethral resection of bladder tumor and was discharged without a complication.

The patient and his relatives gave consent for this case report.

\section{Discussion}

PUBS is a rare and relatively benign clinical situation and commonly associated with the UTI in patients with urinary catheter. PUBS has been reported as a benign, harmless and asymptomatic situation in most studies $(5,6,7,8,9,10,11,12)$. There are some high-risk clinical situations for PUBS patients, such as those who are elderly, women, immobilized patients, patients with an indwelling catheter, chronic constipation, alkaline urine, or poor hygiene, and those with catheter bags and tubes made of certain types of plastic. One of the other reasons for the occurrence of PUBS is the increased concentration of bacteria in the urine as a result of urinary outflow obstruction $(5,13)$.

The UTI has been considered as the main cause, and trigger of PUBS and some pathogens such as Escherichia coli (28\%), Enterococcus species (13\%), Pseudomonas aeruginosa (6\%), Providencia retgerii (8\%), Klebsiella pneumoniae (9\%), Citrobacter species, group B Streptococci (2\%) and Morganella morganii were found as responsible (4). The causative bacteria produce sulphatases and phosphatases through tryptophan metabolism and these reactions result in the formation of indigo and indirubin pigments. The purple color comes from chemicals resulting from this tryptophan metabolism. Interaction between the plastic urine bag and the aforementioned pigments, as well as a high bacterial load, is important precipitating factor for PUBS $(6,7,8,9)$.

M. morganii is an opportunistic infection often seen in postoperative wound and urinary tract infections. According to literature, M. morganii is very rarely associated with PUBS and underlying-associated urothelial cancer has not been reported yet (4). Liu et al. (14) considered M. morganii as an opportunistic and a non-neglient pathogen and they reported that this pathogen might be considered as a cause of PUBS. Our patient had a different clinical scenario from the other cases in the literature. First, according to literature, the plastic urinary catheters were found as responsible in PUBS and whole cases in the literature with PUBS had a urinary catheter at admission (4). However, our patient admitted to emergency department with purple discoloration of urine had no urinary catheter. Second, there is no case report demonstrating an association between the newly diagnosed cancer and UTI with PUBS. In literature review, we did not encounter a case with PUBS, who had no indwelling catheter at the time of diagnosis. Our patient had serious comorbid situations and a urinary catheter insertion history before the latest admission. Underlying urothelial cancer, accompanying comorbid situations might differentiate this patient from previous reports and explain this situation.

Morganella morganii has been known as a rare opportunistic pathogen that is associated with the infection of urinary tract 
(14). However, it is rarely associated with PUBS, there is no report demonstrating that this pathogen was a preliminary finding of urothelial cancer. Malignant urothelial cancer accompanying UTI was probably the main cause of this unique and distinctive clinical situation. Although there is no direct relation between the urothelial cancer and PUBS, all these comorbid situations, atypical pathogen and previous urinary catheter insertion might have caused to this clinical scenario. The isolation of an atypical pathogen as the cause of UTI might be an important clue for differential diagnosis.

\section{Ethics}

Informed Consent: The patient and his relatives gave consent for this case report.

Peer-review: Externally peer-reviewed.

\section{Authorship Contributions}

Concept: Ü.K., P.B.K., P.Ö., K.K., Design: Ü.K., P.B.K., P.Ö., K.K., Literature Search: Ü.K., P.B.K., P.Ö., K.K., Writing: Ü.K., P.B.K.

Conflict of Interest: No conflict of interest was declared by the authors.

Financial Disclosure: The authors declared that this study received no financial support.

\section{References}

1. Khan F, Chaudhry MA, Qureshi N, Cowley B. Purple urine bag syndrome: an alarming hue? A brief review of the literature. Int J Nephrol. 2011;2011:419213. [Crossref]
2. Al Montasir A, Al Mustaque A. Purple urine bag syndrome. J Family Med Prim Care. 2013;2:104-105. [Crossref]

3. Peters P, Merlo J, Beech N, Giles C, Boon B, Parker B, et al. The purple urine bag syndrome: a visually striking side effect of a highly alkaline urinary tract infection. Can Urol Assoc J. 2011;5:233-234. [Crossref]

4. Kalsi DS, Ward J, Lee R, Handa A. Purple urine bag syndrome: a rare spot diagnosis. Dis Markers. 2017;2017:9131872. [Crossref]

5. Yang HW, Su YJ. Trends in the epidemiology of purple urine bag syndrome: A systematic review. Biomed Rep. 2018;8:249-256. [Crossref]

6. Le Mouel JP, Fumery M. Purple urine bag syndrome. Eur J Intern Med. 2018;55:1-2. [Crossref]

7. Traynor BP, Pomeroy E, Niall D. Purple urine bag syndrome: a case report and review of the literature. Oxf Med Case Reports. 2017;2017:omx059. [Crossref]

8. Jain N, Ramrakhiani N, Dubey R. Purple urine bag syndrome: a striking manifestation of urinary tract infection in chronic catherised patients. Int J Sci Res. 2019;8:6. [Crossref]

9. Wattanapisit S, Wattanapisit A, Meepuakmak A, Rakkapan P. Purple urine bag syndrome in palliative care. BMJ Support Palliat Care. 2019;9:155-157. [Crossref]

10. Hadano Y, Shimizu T, Takada S, Inoue T, Sorano S. An update on purple urine bag syndrome. Int J Gen Med. 2012;5:707-710. [Crossref]

11. Pillai BP, Chong VH, Yong AM. Purple urine bag syndrome. Singapore Med J. 2009;50:193-194. [Crossref]

12. Wang IK, Ho DR, Chang HY, Lin CL, Chuang FR. Purple urine bag syndrome in a hemodialysis patient. Intern Med. 2005;44:859-861. [Crossref]

13. Mantani N, Ochiai H, Imanishi N, Kogure T, Terasawa K, Tamura JI. A casecontrol study of purple urine bag syndrome in geriatric wards. J Infect Chemother. 2003;9:53-57. [Crossref]

14. Liu H, Zhu J, Hu O, Rao X. Morganella morganii, a non-negligent opportunistic pathogen. Int J Infect Dis. 2016;50:10-17. [Crossref] 